\title{
High prevalence of syndromic disorders in patients with non-isolated central precocious puberty
}

\author{
Selmen Wannes ${ }^{1}$, Monique Elmaleh-Bergès ${ }^{2}$, Dominique Simon ${ }^{1,5}$, Delphine Zénaty ${ }^{1,5}$, Laetitia Martinerie ${ }^{1,4,5}$, \\ Caroline Storey1, Georges Gelwane1, Anne Paulsen', Emmanuel Ecosse', Nicolas De Roux ${ }^{3,4,5}$, \\ Jean Claude Carel ${ }^{1,4,5}$ and Juliane Léger ${ }^{1,4,5}$
}

${ }^{1}$ Assistance Publique-Hôpitaux de Paris, Robert Debré University Hospital, Endocrinology-Diabetology Department, Reference Center for Endocrine Growth and Developmental Diseases, Paris, France, ${ }^{2}$ Assistance Publique-Hôpitaux de Paris, Pediatric Radiology Department, Robert Debré University Hospital, Paris, France, ${ }^{3}$ Assistance Publique-Hôpitaux de Paris, Biochemistry Unit, Robert Debré University Hospital, Paris, France, ${ }^{4}$ Paris Diderot University, Sorbonne Paris Cite, Paris, France, and ${ }^{5}$ Institut National de la Santé et de la Recherche Médicale (INSERM), UMR 1141, DHU Promoting Research Oriented Towards Early Central Nervous System Therapies (PROTECT), Paris, France

Correspondence should be addressed to J Léger

Email

juliane.leger@aphp.fr

\begin{abstract}
Objective: Non-idiopathic CPP is caused by acquired or congenital hypothalamic lesions visible on MRI or is associated with various complex genetic and/or syndromic disorders. This study investigated the different types and prevalence of non-isolated CPP phenotypes.

Design and Methods: This observational cohort study included all patients identified as having non-idiopathic CPP in the database of a single academic pediatric care center over a period of 11.5 years. Patients were classified on the basis of MRI findings for the CNS as having either hypothalamic lesions or complex syndromic phenotypes without structural lesions of the hypothalamus.

Results: In total, 63 consecutive children (42 girls and 21 boys) with non-isolated CPP were identified. Diverse diseases were detected, and the hypothalamic lesions visible on MRI ( $n=28,45 \%$ of cases) included hamartomas ( $n=17$; either isolated or with an associated syndromic phenotype), optic gliomas ( $n=8$; with or without neurofibromatosis type 1), malformations $(n=3)$ with interhypothalamic adhesions $(n=2$; isolated or associated with syndromic CNS midline abnormalities, such as optic nerve hypoplasia, ectopic posterior pituitary) or arachnoid cysts $(n=1)$. The patients with non-structural hypothalamic lesions ( $n=35,55 \%$ of cases) had narcolepsy $(n=9)$, RASopathies $(n=4)$, encephalopathy or autism spectrum disorders with or without chromosomal abnormalities $(n=15)$ and other complex syndromic disorders $(n=7)$.

Conclusion: Our findings suggest that a large proportion (55\%) of patients with non-isolated probable non-idiopathic CPP may have complex disorders without structural hypothalamic lesions on MRI. Future studies should explore the pathophysiological relevance of the mechanisms underlying CPP in these disorders.

\section{Introduction}

Central precocious puberty (CPP) may have serious underlying causes, including acquired and congenital central nervous system (CNS) lesions or congenital causes without CNS lesions, such as complex syndromic phenotypes with or without known chromosomal abnormalities or genetic changes $(1,2)$. Extremely rare defects of the kisspeptin pathway (the KISS1 and KISS1R genes) $(3,4)$ have recently been implicated in this 
condition, as have mutations of the paternally inherited DLK1 gene (5) and much more frequent heterozygous loss-of-function mutations of the maternally imprinted MKRN3 gene expressed solely from the paternal allele and reported in familial cases with apparently idiopathic CPP (6).

Immediately after CPP diagnosis, patients should undergo etiological diagnostic workup, including neuroimaging. Patients adopted internationally or those without CNS lesions, without acquired conditions (such as early exposure to sex steroids, secondary CPP) or without known underlying disorders are often considered to have 'idiopathic' CPP, which is the most frequent diagnosis (7).

A knowledge of the different clinical forms of nonisolated CPP (i.e. with a CNS lesion or an underlying disorder) is therefore essential when evaluating children with $\mathrm{CPP}$, to ensure that they are appropriately managed by experienced clinicians, including oncologists, surgeons, geneticists and neurologists, and that GnRH agonist treatment leads to the regression or stabilization of pubertal symptoms $(1,2)$.

A few groups have reported the epidemiology of non-isolated CPP either at their own institutions $(7,8,9$, $10,11)$ or over multiple institutions $(12,13,14)$. These studies were limited by the inclusion solely of patients with CNS lesions only, with other associated disorders being evaluated imprecisely, mostly through case reports $(15,16,17,18,19)$

Based on clinical experience at our institution, we suspected there could be a high prevalence of associated disorders among patients with non-isolated CPP. We tested this hypothesis in a large cohort of patients, with a view to obtaining additional data concerning disorders associated with CPP or creating a predisposition to this condition. The aim of this study was to evaluate the prevalence and types of non-isolated CPP in a large group of consecutive patients with CPP.

\section{Patients and methods}

This observational cohort study included all patients identified as having non-isolated CPP (from our entire cohort of patients with CPP, $n=396$ ) in the database of the Pediatric Endocrinology Department of Robert Debré Hospital in Paris between January 2006 and June 2017. CPP was diagnosed on the basis of breast development before the age of eight years in girls and testicular enlargement before the age of 9.5 years in boys, together with evaluations of serum gonadotropin-releasing hormone (GnRH) activation, based on serum LH levels, mostly after stimulation with exogenous GnRH or menarche occurrence before the age of 10 years. We excluded patients with isolated CPP, CPP due to known mutations of the MKRN3 gene (familial cases with isolated CPP) (20), previous irradiation of the brain or early exposure to sex steroids, and patients who had been adopted internationally.

\section{Study protocol}

Clinical data for the patients were obtained from their medical records. Demographic characteristics, including personal medical history and known associated abnormalities (e.g. neurodevelopmental or syndromic phenotypes with or without chromosomal abnormalities), sex, age at first pubertal symptoms, age, bone age, height, weight, pubertal stage and biological data concerning hypothalamic-pituitary function at diagnosis and during follow-up were recorded, together with brain MRI findings.

The causes of CPP were grouped into the following categories: pathological CNS features with hypothalamic lesions on brain MRI and non-hypothalamic MRI findings in patients with associated syndromes and chromosomal or molecular disorders.

\section{Methods}

Precocious puberty (PP) has been defined as the onset of clinical signs of puberty before the age of 9.5 years in boys (testicular enlargement) and before 8 years in girls (breast development) or the occurrence of menarche before the age of 10 years $(n=5)$. The hypothalamic-pituitarygonad axis was assessed by measuring gonadotropin responses in the GnRH stimulation test (serum LH and FSH concentrations determined at baseline and 20, 40, 60 and $90 \mathrm{~min}$ after intravenous bolus administration of $100 \mu \mathrm{g} / \mathrm{m}^{2} \mathrm{GnRH}$; central PP diagnosed if LH peak $>5 \mathrm{IU} / \mathrm{L}$ ), and plasma concentrations of testosterone in boys and estradiol in girls. Girls also underwent pelvic ultrasound scans. A longitudinal uterus diameter of more than $35 \mathrm{~mm}$, a pear-shaped uterus and endometrial thickening were considered to be signs of estrogenic stimulation (1).

Anterior pituitary function was evaluated if considered necessary on the basis of signs of endocrine dysfunction (hypoglycemia or a decrease in growth velocity) and/or 
midline abnormalities on MRI. Growth hormone deficiency was diagnosed on the basis of low serum IGF-I concentration and a serum growth hormone peak of less than $10 \mu \mathrm{g} / \mathrm{L}$ or $20 \mathrm{mIU} / \mathrm{L}$ in a pharmacological stimulation test or during spontaneous hypoglycemia. Thyroid-stimulating hormone deficiency was diagnosed on the basis of a serum free $\mathrm{T} 4$ concentration below $10 \mathrm{pmol} / \mathrm{L}$. Adrenocorticotropic hormone (ACTH) deficiency was diagnosed on the basis of morning basal serum cortisol concentrations below $180 \mathrm{nmol} / \mathrm{L}$ and/or below $450 \mathrm{nmol} / \mathrm{L}$ during hypoglycemia or on the basis of low-dose short tetracosactide (Synacthen) tests. The corticotrophin reserve was not systematically evaluated if morning cortisol concentrations exceeded $275 \mathrm{nmol} / \mathrm{L}$.

Height, growth velocity, weight and BMI (weight (kilograms)/height (meters) ${ }^{2}$ ) were expressed as the SDS for sex and chronological age $(21,22)$. Pubertal development was assessed by determining Tanner stage. Bone age was determined by the Greulich and Pyle method. Target height was calculated from midparental height. Features of syndromic phenotypes with or without chromosomal abnormalities were carefully assessed individually, by a pediatric endocrinologist and a geneticist either before or after CPP diagnosis. Brain MRI was carried out at CPP diagnosis. All MRI images (1.5 Tesla Magnet Philips Intera, Philips Medical Systems, The Netherlands) were reviewed by the same investigator (ME). Sagittal and coronal thin $(1.5 \mathrm{~mm})$ slices of the hypothalamic-pituitary area were acquired with a gradient echo T1-weighted sequence, and coronal slices of the brain were acquired with a T2-weighted sequence. Any brain abnormalities detected were described. The MRI findings were categorized into two groups according to the presence or absence of pathological CNS features involving the hypothalamus area. Genetic and molecular investigations were performed depending on the phenotype.

\section{Hormone assays}

Serum FSH and LH concentrations were determined in immunochemiluminescence assays (Siemens Healthcare SAS). Serum testosterone and estradiol concentrations were determined by radioimmunoassay (RIA Testosterone Direct, Beckman Coulter-Immunotech and EST-US-CT, Cisbio Bioassays, Gif-sur-Yvette, France). The intra- and inter-assays coefficients of variation were $<3.5$ and $<6.5 \%$, respectively, for $\mathrm{FSH},<4$ and $<6 \%$, respectively, for $\mathrm{LH}$, $<6$ and $<12 \%$, respectively for testosterone and $<10$ and $<13.5 \%$, respectively for estradiol.

\section{Statistical analysis}

The results are expressed as numerical values (percentages) for categorical variables and medians (25-75th percentiles) for continuous variables. Comparisons were performed with chi-squared tests for categorical variables and nonparametric Mann-Whitney or Kruskal-Wallis tests for

Table 1 Distribution of the phenotypes of the patients from the non-isolated CPP cohort at Robert Debré Hospital ( $n=63)$, according to the presence $(n=28)$ or absence $(n=35)$ of hypothalamic lesions visible on brain MRI.

\begin{tabular}{|c|c|}
\hline & $\boldsymbol{n}(\%)$ \\
\hline Hypothalamic lesions on brain MRI & $28(45 \%)$ \\
\hline Hamartoma & $17(27 \%)$ \\
\hline Isolated & 14 \\
\hline Syndromic or associated with: & 3 \\
\hline \multicolumn{2}{|l|}{ Pallister Hall syndrome + EPP } \\
\hline \multicolumn{2}{|l|}{ Mowat-Wilson syndrome ${ }^{a}$} \\
\hline \multicolumn{2}{|l|}{ Hydrocephalus } \\
\hline Glioma & $8(13 \%)$ \\
\hline Isolated & 2 \\
\hline Syndromic (neurofibromatosis type 1) & 6 \\
\hline Others & $3(5 \%)$ \\
\hline Interhypothalamic adhesions (IHA) & 2 \\
\hline \multicolumn{2}{|l|}{ Isolated IHA } \\
\hline \multicolumn{2}{|l|}{ Syndromic IHA with optic nerve } \\
\hline \multicolumn{2}{|l|}{ hypoplasia + EPP } \\
\hline Arachnoid cyst & 1 \\
\hline Without hypothalamic lesions on brain MRI & $35(55 \%)$ \\
\hline Narcolepsy & $9(14 \%)$ \\
\hline Isolated (familial form of CPP, $n=1$ ) & 8 \\
\hline Associated with MPHD & 1 \\
\hline RASopathy & $4(6 \%)$ \\
\hline \multicolumn{2}{|l|}{ Cardiofaciocutaneous syndrome ${ }^{b}$} \\
\hline \multicolumn{2}{|l|}{ Epidermal hamartomac } \\
\hline \multicolumn{2}{|l|}{ Neurofibromatosis type 1} \\
\hline \multicolumn{2}{|l|}{ Ito hypomelanosis } \\
\hline $\begin{array}{l}\text { Encephalopathy and/or autism spectrum } \\
\text { disorder (ASD) }\end{array}$ & $15(24 \%)$ \\
\hline Other genetic syndromic disorders & $7(11 \%)$ \\
\hline Silver-Russell syndrome & 1 \\
\hline Temple syndrome $^{f}$ & 2 \\
\hline Williams-Beuren syndrome ${ }^{g}$ & 1 \\
\hline Kabuki syndrome ${ }^{h}$ & 1 \\
\hline T21 (Down's syndrome) & 1 \\
\hline Usher syndrome (type 1$)^{\mathrm{i}}$ & 1 \\
\hline \multicolumn{2}{|c|}{ 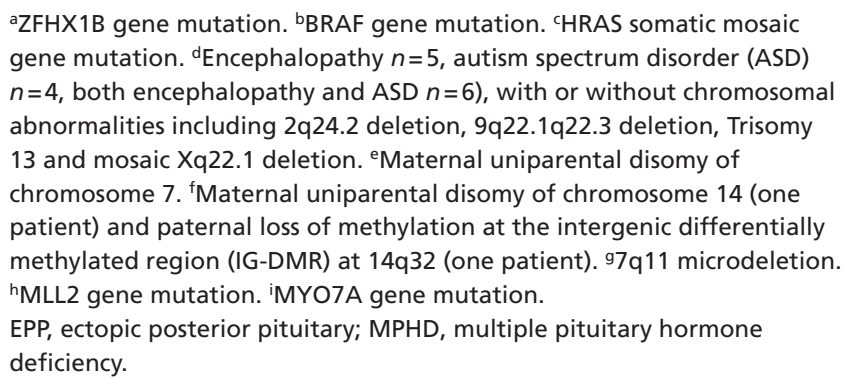 } \\
\hline
\end{tabular}


continuous variables. All statistical analyses were carried out with SAS software, version 9.12 (SAS Institute Inc.).

\section{Ethics approval}

This study was approved by the Ethics Review Committee for Biomedical Research Projects Robert Debré University Hospital, AP-HP (no. 2014-158). Informed consent was obtained from the parents.

\section{Results}

In total, 63 consecutive children (42 girls and 21 boys) with non-isolated CPP (16\% of our entire cohort of patients with CPP followed during the study period) were identified. Their phenotypes are displayed in Table 1, according to the presence $(n=28)$ or absence $(n=35)$ of visible hypothalamic lesions on MRI of the CNS. We identified a broad spectrum of diseases in patients with visible hypothalamic lesions, including hamartomas ( $n=17$ isolated or associated with a syndromic phenotype), with one patient $(n=1)$ having more than one hamartoma (Mowat-Wilson syndrome), gliomas ( $n=8$; isolated or associated with neurofibromatosis type 1 (NF1)) and malformations $(n=3)$ with either interhypothalamic adhesions (IHA) $(n=2$, isolated or associated with syndromic CNS midline abnormalities: optic nerve hypoplasia and ectopic posterior pituitary) or arachnoid cyst $(n=1)$. Patients with no hypothalamic lesions visible on MRI had narcolepsy $(n=9)$, RASopathies $(n=4)$, encephalopathy and/or autism spectrum disorders $(n=15)$ of varying neurological severity, with or without chromosomal abnormalities including 2 (del 2 q24.2, associated with severe intellectual disability and epilepsy), 9 (del 9q22.1q22.3, associated with autism spectrum disorder), 13 (trisomy 13, associated with severe intellectual disability and epilepsy), X (mosaic del Xq22.1, associated with cerebral palsy and spastic quadriplegia) and other chromosomal or molecular disorders $(n=7)$.

The clinical characteristics of the patients at the time of CPP diagnosis are shown according to the presence or absence of pathological CNS images in the hypothalamus region (Table 2). Patients with hypothalamic lesions were significantly younger $(P<0.01)$ with a significantly greater BA/CA $(P<0.01)$ at the time of CPP diagnosis and with an earlier onset of clinical signs of puberty $(P<0.01)$ than patients without pathological MRI findings for the hypothalamus area. Within the two groups with and without hypothalamus lesions, the ages of the individuals at the time of CPP diagnosis differed among the seven
Table 2 Characteristics of the 63 patients with non-isolated CPP according to the presence or absence of hypothalamic lesions on MRI.

\begin{tabular}{|c|c|c|}
\hline & $\begin{array}{c}\text { Patients with } \\
\text { hypothalamic } \\
\text { lesion on MRI }(n=28)\end{array}$ & $\begin{array}{l}\text { Patients without } \\
\text { CNS hypothalamic } \\
\text { lesions on MRI } \\
(n=35)\end{array}$ \\
\hline Male $(n, \%)$ & $10(36)$ & $11(31)$ \\
\hline $\begin{array}{l}\text { Age at puberty onset, } \\
\text { years }\end{array}$ & $4.95(1.60 ; 7.50)$ & $7.30(6.00 ; 7.80)$ * \\
\hline $\begin{array}{l}\text { Age at evaluation, } \\
\text { years }\end{array}$ & $6.44(3.37 ; 8.54)$ & $8.61(6.91 ; 9.08)$ * \\
\hline \multicolumn{3}{|l|}{$\begin{array}{l}\text { Tanner stage at } \\
\text { evaluation: }\end{array}$} \\
\hline Tanner $2, n$ & 15 & 11 \\
\hline Tanner 3, $n$ & 11 & 16 \\
\hline Tanner $4, n$ & 1 & 6 \\
\hline Tanner 5, $n$ & - & 2 \\
\hline Target height SDS & $0.73(0.16 ; 1.66)$ & $0.04(-0.37 ; 0.88)$ \\
\hline Height SDS & $1.47(0.57 ; 2.45)$ & $1.32(-0.02 ; 2.21)$ \\
\hline BMI SDS & $1.21(0.73 ; 2.34)$ & $1.46(0.31 ; 2.40)$ \\
\hline $\begin{array}{l}\text { Ratio bone } \\
\text { age/chronological age }\end{array}$ & $1.40(1.18 ; 1.83)$ & $1.27(1.17 ; 1.32)$ * \\
\hline LH peak (iU/L) & $20(12.25 ; 35.80)$ & $24(9.60 ; 30.90)$ \\
\hline LH-FSH peak ratio & $1.86(1.18 ; 3.27)$ & $1.93(0.78 ; 2.70)$ \\
\hline Estradiol (pg/mL) & $14.5(10.0 ; 22.8)$ & $13.0(7.5 ; 25.0)$ \\
\hline Testosterone (ng/mL) & $0.73(0.40 ; 1.10)$ & $1.19(0.36 ; 2.50)$ \\
\hline $\begin{array}{l}\text { Associated hormonal } \\
\text { deficit }\end{array}$ & $\begin{array}{l}\text { MPHD } n=5^{\mathrm{a}} \\
\text { IGHD } n=3^{\mathrm{b}}\end{array}$ & $\begin{array}{l}\operatorname{MPHD}^{c} n=1^{* *} \\
\operatorname{IGHD}^{d} n=1\end{array}$ \\
\hline
\end{tabular}

Values are expressed as median \pm quartiles.

aHypothalamic hamartoma $(n=2)$, interhypothalamic adhesion $(n=1)$ and glioma without neurofibromatosis type 1 (NF1) $(n=2)$. b Optic pathway glioma with NF1 $(n=2)$ and arachnoid cyst $(n=1)$. 'Narcolepsia.

${ }^{d}$ Encephalopathy and autism spectrum disorder. ${ }^{*} P<0.01 ; * * P<0.02$. IGHD, isolated growth hormone deficiency; MPHD, multiple pituitary hormone deficiency; SDS, standard deviation score.

clinical subgroups (Fig. 1). Patients with hamartomas were significantly younger at puberty onset and at the time of CPP diagnosis $(P<0.05)$. They had a significantly higher BA/CA and slightly higher basal and peak LH concentrations at the time of CPP diagnosis than those with other pathological findings on MRI (Fig. 1, Table 3). No other parameter differed significantly among the groups. Interestingly, median BMI was 1.24 (0.45-2.34) SDS for the entire group and did not differ between subgroups (Table 3 ).

Associated anterior pituitary dysfunctions were more frequent in patients with hypothalamic lesion on MRI than in those with no visible hypothalamic lesions: $n=8$ (28.6\%) vs $n=2(5.7 \%)(P=0.01)$, (Tables 2 and 3$)$.

\section{Discussion}

We demonstrate here that, in this cohort, non-isolated CPP was associated with similar prevalence of the 


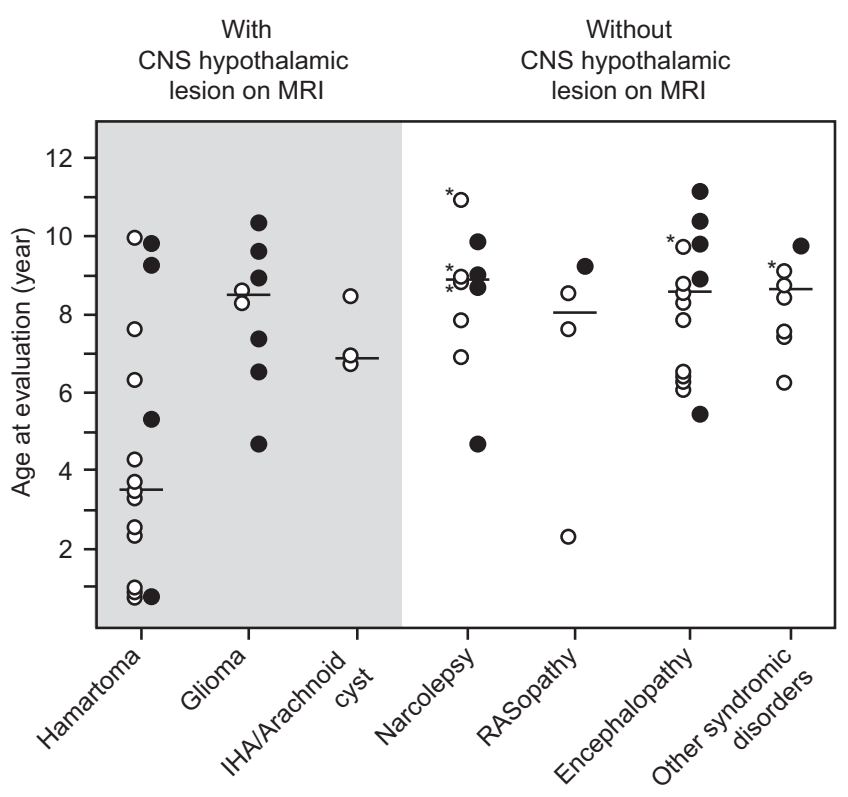

Figure 1

Age at evaluation of the individuals, by patient subgroup, with and without visible hypothalamic lesions on MRI. The bar indicates the median values. Girls are indicated by open circles, whereas the boys are indicated by closed circles. *Patients with precocious menarche (at 8.5, 8.9, 9.0, 9.4 and 9.7 years, respectively).

presence and absence of structural lesions of the hypothalamus on MRI (45 vs 55\%). These findings suggest that the association of non-isolated CPP with syndromic disorders is at least as frequent as its association with hypothalamic tumors or lesions. This study is the first to analyze phenotypes in detail in both patients with non-idiopathic CPP and hypothalamic lesions, and in patients with other associated disorders with no structural lesions of the hypothalamus on MRI. No study assessing non-idiopathic CPP in a large population comprising these two subgroups of patients has ever been reported. Female predominance was observed in all subgroups except the optic glioma group, but it was weaker than in idiopathic CPP. As expected, hamartomas and optic gliomas were the most frequent etiologies observed in patients with hypothalamic lesions on MRI, but complex syndromic phenotypes were observed in many other conditions without structural lesions of the hypothalamus on MRI. These syndromes include narcolepsy, RASopathy, encephalopathy and other diverse chromosomal abnormalities or genomic imprinting disorders that might induce PP by activating the hypothalamic-pituitary-gonadal axis.
Hamartoma and optic glioma result from lesions of the hypothalamus. In our case series, hamartomas, whether isolated or syndromic, were the most frequent underlying diagnosis. As previously reported, patients with hypothalamic hamartoma developed CPP at a younger age and displayed faster growth, leading to greater height, more advanced bone maturation and slightly stronger gonadotropin responses after the administration of exogenous $\mathrm{GnRH}$ than were observed in other children with CPP $(12,23)$. Hamartomas are noninvasive heterotopic structures that can trigger an increase in GnRH levels through undetermined mechanisms (24, 25). Optic gliomas with or without NF1, and arachnoid cysts have also frequently been described in association with CPP $(9,10)$. The mechanisms involved have, again, not been characterized, but are related to hypothalamic dysfunction and possibly to compression or infiltration of the hypothalamic area $(26,27)$. Interhypothalamic adhesions consist of a band of tissue isointense to gray matter on T2 sequences of MRI, spanning the anterior recess of the third ventricle. They are less frequently described and are rarely associated with midline developmental abnormalities, as shown by the very small number of cases reported to date. The underlying etiology of IHA remains unclear, but it has been suggested that IHA results from incomplete hypothalamus cleavage, failed apoptosis or abnormal neuronal migration $(28,29)$. Endocrine dysfunction with anterior pituitary deficiency has been reported in only three patients with IHA (29). An association of developmental defects of the hypothalamic-pituitary area, such as septo-optic dysplasia and/or ectopic posterior pituitary, with CPP has been reported in a few cases $(30,31,32)$, but no similar case of CPP and IHA has ever been described, to our knowledge.

Other types of non-idiopathic CPP were found in this study to be probably associated with genetic disorders with no structural hypothalamic lesions on MRI. None of our patients had hydrocephalus or structural abnormalities known to be associated with non-idiopathic CPP. It therefore seems unlikely that compression or high intracranial pressure played a role in the etiology of CPP in these patients. An impairment of the central activation of the hypothalamic-pituitary-gonadal axis is likely, although the underlying pathophysiological mechanism is yet to be clearly determined.

The prevalence of CPP in children with cerebral palsy and moderate or severe motor impairment is unknown, as the available data are limited $(15,33,34)$. A higher prevalence of variable degrees of early sexual maturation was reported in 161 girls with neonatal encephalopathy 


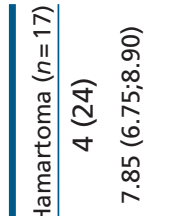

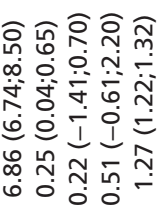

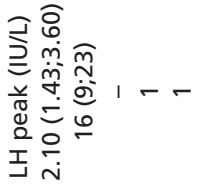

I

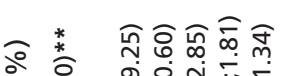

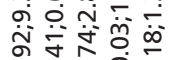
ध 过

$\stackrel{\frac{1}{10}}{\Sigma} \frac{0}{i}$

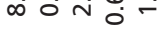

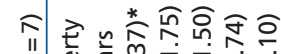
至

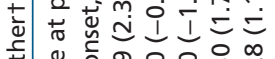
๖ món

$\frac{\pi}{\pi}$

ํํㄹㅇำ

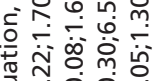

元

यับ

苂

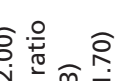

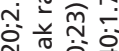

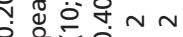

은등

님

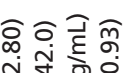

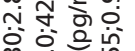

要

응응 응

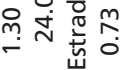

으ำ 을 है

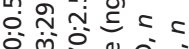

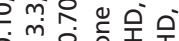

응응원

ণ্ড

จิ

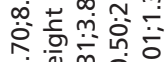

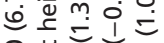

ํํำ ํํㄴำ

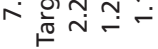

응으 $\widehat{\circ} \overline{\mathrm{m}}$

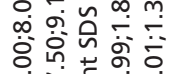

윤 등응

융요

๑ $\infty$

응오ํ

ํํำ ํํㅇ

능원ำ

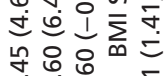

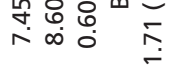

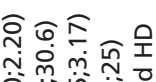

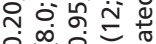

잉 0

웜

\section{ธิกิร}

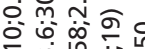

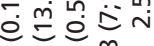

울

实市

\section{ㅇํำ}

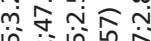

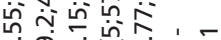

e

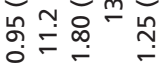

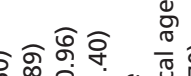

$\frac{\pi}{0}$ 응

ర人

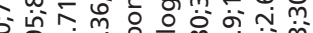

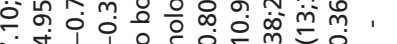

i

ก 0 은

$\wedge \infty \stackrel{1}{\circ}$

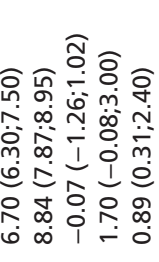

than in the general population (4.3 vs $0.6 \%)$ (35). As expected, our patients also frequently displayed other types of alteration to brain structure (data not shown). It has been suggested that severe brain damage and antiepileptic drugs probably affect neurotransmitter pathways involved in gonadotropin control and that the normal hypothalamic inhibition of gonadotropins may be lost (34).

Limited data have also been reported for patients with RASopathies and CPP, such as our patients with cardio facio cutaneous syndrome (BRAF mutation) $(19,36)$ or epidermal nevus syndrome with HRAS gene mutation (37, 38, 39). Ras-Raf-mEK-ERK signaling is impaired in these cases, but the precise mechanism leading to CPP remains unknown.

Narcolepsy, a complex disorder characterized by CNS hypersomnia due to a dysfunction of hypocretin neurons, has been reported to be associated with hypothalamic dysfunction, including rapid-onset obesity and CPP. The link between this disorder, CPP and obesity remains unclear $(40,41)$.

Other complex developmental syndromes involving genetic or epigenetic abnormalities have been shown to be associated with CPP in case reports. Such associations were found in this study for patients with Silver-Russell and Temple syndromes (maternal uniparental disomy of chromosome 7 and paternal imprinted disruption or maternal uniparental disomy on chromosome 14, respectively) (42), Williams-Beuren syndrome (7q11.23 microdeletion) (17) and Kabuki syndrome (MLL2 gene mutation) (18). In other chromosomal abnormalities, incidental association could not be excluded, but rare clinical cases have already been reported $(15,16,43)$.

The strengths of this study are that all patients in a defined population from a single pediatric clinical center for whom the timing of puberty had been ascertained and comprehensive data collected were included. It was, therefore, possible to evaluate subgroups of individuals with different disorders. The main limitation of our study was the observational nature of retrospective data collection. Despite the brain MRI data available for all patients, this study provides no further insight into the mechanism underlying CPP. It is also impossible to draw any firm conclusions regarding causality in CPP patients with syndromic and/or chromosomal abnormalities but no structural lesions of the hypothalamus on MRI. For these patients, it was not possible to control for potential familial cases, which might have affected puberty timing due to genetic or epigenetic mechanisms. 
In conclusion, this study provides evidence to suggest that hypothalamic disturbances not visible on MRI may be associated with several complex disorders in patients with non-isolated and potentially non-idiopathic CPP. However, this study cannot identify the etiology of this association, which remains to be elucidated.

These original findings have important clinical implications for patient management, as they highlight the need for appropriate careful monitoring for the early recognition and treatment of CPP in patients with such disorders, potentially improving their long-term outcomes. We also describe, for the first time, the association of IHA with CPP in a context of midline malformation.

Our observations reflect the exceeding complexity of the onset of puberty. Future studies should explore the pathophysiological relevance of mechanisms underlying the precocious onset of puberty in these disorders and possible overlap between them.

\section{Declaration of interest}

J Léger is an editor of the journal (European Journal of Endocrinology). Other authors have no conflicts of interest relevant to this manuscript to disclose.

\section{Funding}

This study was supported in part by the French Ministry of Health (Rare Disease Plan). Selmen Wannes held a clinical research fellowship from the European Society for Paediatric Endocrinology. Data collection, analysis and interpretation, and the decision to submit the paper for publication were the responsibility of the authors alone. The funding sources had no role in study design, data collection, data interpretation, data analysis or the writing of the report.

\section{References}

1 Carel JC \& Leger J. Clinical practice. Precocious puberty. New England Journal of Medicine 2008358 2366-2377. (https://doi.org/10.1056/ NEJMcp0800459)

2 Latronico AC, Brito VN \& Carel JC. Causes, diagnosis, and treatment of central precocious puberty. Lancet Diabetes and Endocrinology 2016 4 265-274. (https://doi.org/10.1016/S2213-8587(15)00380-0)

3 Silveira LG, Noel SD, Silveira-Neto AP, Abreu AP, Brito VN, Santos MG, Bianco SD, Kuohung W, Xu S, Gryngarten M et al. Mutations of the KISS1 gene in disorders of puberty. Journal of Clinical Endocrinology and Metabolism 201095 2276-2280. (https:// doi.org/10.1210/jc.2009-2421)

4 Teles MG, Bianco SD, Brito VN, Trarbach EB, Kuohung W, Xu S, Seminara SB, Mendonca BB, Kaiser UB \& Latronico AC. A GPR54activating mutation in a patient with central precocious puberty. New England Journal of Medicine 2008358 709-715. (https://doi. org/10.1056/NEJMoa073443)

5 Dauber A, Cunha-Silva M, Macedo DB, Brito VN, Abreu AP, Roberts SA, Montenegro LR, Andrew M, Kirby A, Weirauch MT et al. Paternally inherited DLK1 deletion associated with familial central precocious puberty. Journal of Clinical Endocrinology and Metabolism 2017102 1557-1567. (https://doi.org/10.1210/jc.2016-3677)
6 Abreu AP, Dauber A, Macedo DB, Noel SD, Brito VN, Gill JC, Cukier P, Thompson IR, Navarro VM, Gagliardi PC et al. Central precocious puberty caused by mutations in the imprinted gene MKRN3. New England Journal of Medicine 2013368 2467-2475. (https://doi. org/10.1056/NEJMoa1302160)

7 Mogensen SS, Aksglaede L, Mouritsen A, Sorensen K, Main KM, Gideon P \& Juul A. Diagnostic work-up of 449 consecutive girls who were referred to be evaluated for precocious puberty. Journal of Clinical Endocrinology and Metabolism 201196 1393-1401. (https:// doi.org/10.1210/jc.2010-2745)

8 Chemaitilly W, Trivin C, Adan L, Gall V, Sainte-Rose C \& Brauner R. Central precocious puberty: clinical and laboratory features. Clinical Endocrinology 200154 289-294. (https://doi.org/10.1046/j.13652265.2001.01229.x)

9 Trivin C, Couto-Silva AC, Sainte-Rose C, Chemaitilly W, Kalifa C, Doz F, Zerah M \& Brauner R. Presentation and evolution of organic central precocious puberty according to the type of CNS lesion. Clinical Endocrinology 200665 239-245. (https://doi.org/10.1111/ j.1365-2265.2006.02582.x)

10 Mogensen SS, Aksglaede L, Mouritsen A, Sorensen K, Main KM, Gideon P \& Juul A. Pathological and incidental findings on brain MRI in a single-center study of 229 consecutive girls with early or precocious puberty. PLOS ONE 20127 e29829. (https://doi. org/10.1371/journal.pone.0029829)

11 Pedicelli S, Alessio P, Scire G, Cappa M \& Cianfarani S. Routine screening by brain magnetic resonance imaging is not indicated in every girl with onset of puberty between the ages of 6 and 8 years. Journal of Clinical Endocrinology and Metabolism 201499 4455-4461. (https://doi.org/10.1210/jc.2014-2702)

12 De Sanctis V, Corrias A, Rizzo V, Bertelloni S, Urso L, Galluzzi F, Pasquino AM, Pozzan G, Guarneri MP, Cisternino M et al. Etiology of central precocious puberty in males: the results of the Italian Study Group for Physiopathology of Puberty. Journal of Pediatric Endocrinology and Metabolism 200013 (Supplement 1) 687-693.

13 Cisternino M, Arrigo T, Pasquino AM, Tinelli C, Antoniazzi F, Beduschi L, Bindi G, Borrelli P, De Sanctis V, Farello G et al. Etiology and age incidence of precocious puberty in girls: a multicentric study. Journal of Pediatric Endocrinology and Metabolism 200013 (Supplement 1) 695-701.

14 Soriano-Guillen L, Corripio R, Labarta JI, Canete R, Castro-Feijoo L, Espino R \& Argente J. Central precocious puberty in children living in Spain: incidence, prevalence, and influence of adoption and immigration. Journal of Clinical Endocrinology and Metabolism 201095 4305-4313. (https://doi.org/10.1210/jc.2010-1025)

15 Saletti V, Canafoglia L, Cambiaso P, Russo S, Marchi M \& Riva D. A CDKL5 mutated child with precocious puberty. American Journal of Medical Genetics Part A 2009 149A 1046-1051. (https://doi. org/10.1002/ajmg.a.32806)

16 Dhar SU, Robbins-Furman P, Levy ML, Patel A \& Scaglia F. Tetrasomy 13q mosaicism associated with phylloid hypomelanosis and precocious puberty. American Journal of Medical Genetics Part A 2009 149A 993-996. (https://doi.org/10.1002/ajmg.a.32758)

17 Partsch CJ, Japing I, Siebert R, Gosch A, Wessel A, Sippell WG \& Pankau R. Central precocious puberty in girls with Williams syndrome. Journal of Pediatrics 2002141 441-444. (https://doi. org/10.1067/mpd.2002.127280)

18 Kuroki Y, Katsumata N, Eguchi T, Fukushima Y, Suwa S \& Kajii T. Precocious puberty in Kabuki makeup syndrome. Journal of Pediatrics 1987110 750-752. (https://doi.org/10.1016/S0022-3476(87)80018-5)

19 van der Kaay DC, Levine BS, Doyle D, Mendoza-Londono R \& Palmert MR. RASopathies are associated with delayed puberty; are they associated with precocious puberty too? Pediatrics 2016138 e20160182. (https://doi.org/10.1542/peds.2016-0182)

20 Simon D, Ba I, Mekhail N, Ecosse E, Paulsen A, Zenaty D, Houang M, Jesuran Perelroizen M, de Filippo GP, Salerno M et al. Mutations in the maternally imprinted gene MKRN3 are common in familial 
central precocious puberty. European Journal of Endocrinology 2016 174 1-8. (https://doi.org/10.1530/EJE-15-0488)

21 Sempé M, Pédron, G. \& Roy-Pernot, MP Auxologie, méthode et séquences. Paris, France: Théraplix, 1979.

22 Rolland-Cachera MF, Cole TJ, Sempe M, Tichet J, Rossignol C \& Charraud A. Body mass index variations: centiles from birth to 87 years. European Journal of Clinical Nutrition 199145 13-21.

23 Cacciari E, Frejaville E, Cicognani A, Pirazzoli P, Frank G, Balsamo A, Tassinari D, Zappulla F, Bergamaschi R \& Cristi GF. How many cases of true precocious puberty in girls are idiopathic? Journal of Pediatrics 1983102 357-360. (https://doi.org/10.1016/S0022-3476(83)80648-9)

24 Jung H, Carmel P, Schwartz MS, Witkin JW, Bentele KH, Westphal M, Piatt JH, Costa ME, Cornea A, Ma YJ et al. Some hypothalamic hamartomas contain transforming growth factor alpha, a pubertyinducing growth factor, but not luteinizing hormone-releasing hormone neurons. Journal of Clinical Endocrinology and Metabolism 199984 4695-4701.

25 Chan YM, Fenoglio-Simeone KA, Paraschos S, Muhammad L, Troester MM, Ng YT, Johnsonbaugh RE, Coons SW, Prenger EC, Kerrigan JF et al. Central precocious puberty due to hypothalamic hamartomas correlates with anatomic features but not with expression of GnRH, TGFalpha, or KISS1. Hormone Research in Paediatrics 201073 312-319. (https://doi.org/10.1159/000308162)

26 Sani I \& Albanese A. Endocrine long-term follow-up of children with neurofibromatosis type 1 and optic pathway glioma. Horm Res Paediatr 201787 179-188. (https://doi.org/10.1159/000458525)

27 Huang HP, Tung YC, Tsai WY, Kuo MF \& Peng SF. Arachnoid cyst with GnRH-dependent sexual precocity and growth hormone deficiency. Pediatric Neurology 200430 143-145. (https://doi. org/10.1016/S0887-8994(03)00418-1)

28 Whitehead MT \& Vezina G. Interhypothalamic adhesion: a series of 13 cases. American Journal of Neuroradiology 201435 2002-2006. (https://doi.org/10.3174/ajnr.A3987)

29 Ahmed FN, Stence NV \& Mirsky DM. Asymptomatic interhypothalamic adhesions in children. American Journal of Neuroradiology 201637 726-729. (https://doi.org/10.3174/ajnr.A4602)

30 Huseman CA, Kelch RP, Hopwood NJ \& Zipf WB. Sexual precocity in association with septo-optic dysplasia and hypothalamic hypopituitarism. Journal of Pediatrics 197892 748-753. (https://doi. org/10.1016/S0022-3476(78)80142-5)

31 Birkebaek NH, Patel L, Wright NB, Grigg JR, Sinha S, Hall CM, Price DA, Lloyd IC \& Clayton PE. Endocrine status in patients with optic nerve hypoplasia: relationship to midline central nervous system abnormalities and appearance of the hypothalamic-pituitary axis on magnetic resonance imaging. Journal of Clinical Endocrinology and Metabolism 200388 5281-5286. (https://doi.org/10.1210/ jc.2003-030527)

32 Ladjouze A, Soskin S, Garel C, Jullien M, Naud-Saudreau C, Pinto G, Czernichow P \& Leger J. GH deficiency with central precocious puberty: a new rare disorder associated with a developmental defect of the hypothalamic-pituitary area. European Journal of Endocrinology 2007156 463-469. (https://doi.org/10.1530/EJE-06-0688)

33 Siddiqi SU, Van Dyke DC, Donohoue P \& McBrien DM. Premature sexual development in individuals with neurodevelopmental disabilities. Developmental Medicine and Child Neurology 199941 392-395. (https://doi.org/10.1017/S0012162299000857)

34 Bruzzi P, Messina MF, Bartoli A, Predieri B, Lucaccioni L, Madeo SF, Verrotti A, De Luca F \& Iughetti L. Central precocious puberty and response to GnRHa therapy in children with cerebral palsy and moderate to severe motor impairment: data from a Longitudinal, Case-Control, Multicentre, Italian Study. International Journal of Endocrinology 201720174807163.

35 Robertson CM, Morrish DW, Wheler GH \& Grace MG. Neonatal encephalopathy: an indicator of early sexual maturation in girls. Pediatric Neurology 19906 102-108. (https://doi.org/10.1016/08878994(90)90042-Y)

36 Celik N, Cinaz P, Bideci A, Yuce O, Emeksiz HC, Doger E \& Camurdan O. Cardio-facio-cutaneous syndrome with precocious puberty, growth hormone deficiency and hyperprolactinemia. Journal of Clinical Research in Pediatric Endocrinology 20146 55-58. (https:// doi.org/10.4274/Jcrpe.1151)

37 Martin RJ, Arefi M, Splitt M, Redford L, Moss C \& Rajan N. Phacomatosis pigmentokeratotica and precocious puberty associated with HRAS mutation. British Journal of Dermatology 2018178 289-291. (https://doi.org/10.1111/bjd.15643)

38 Moss C, Parkin JM \& Comaish JS. Precocious puberty in a boy with a widespread linear epidermal naevus. British Journal of Dermatology 1991125 178-182. (https://doi.org/10.1111/j.1365-2133.1991. tb06068.x)

39 Tay YK, Weston WL, Ganong CA \& Klingensmith GJ. Epidermal nevus syndrome: association with central precocious puberty and woolly hair nevus. Journal of the American Academy of Dermatology 199635 839-842. (https://doi.org/10.1016/S0190-9622(96)90098-5)

40 Poli F, Pizza F, Mignot E, Ferri R, Pagotto U, Taheri S, Finotti E, Bernardi F, Pirazzoli P, Cicognani A et al. High prevalence of precocious puberty and obesity in childhood narcolepsy with cataplexy. Sleep 201336 175-181. (https://doi.org/10.5665/ sleep.2366)

41 Postiglione E, Antelmi E, Pizza F, Lecendreux M, Dauvilliers Y \& Plazzi G. The clinical spectrum of childhood narcolepsy. Sleep Medicine Reviews 201838 70-85. (https://doi.org/10.1016/j. smrv.2017.04.003)

42 Hoffmann K \& Heller R. Uniparental disomies 7 and 14. Best Practice and Research: Clinical Endocrinology and Metabolism 201125 77-100. (https://doi.org/10.1016/j.beem.2010.09.004)

43 Cisternino M, Della Mina E, Losa L, Made A, Rossetti G, Bassi LA, Pieri G, Bayindir B, Messa J, Zuffardi O et al. Idiopathic central precocious puberty associated with $11 \mathrm{mb}$ de novo distal deletion of the chromosome 9 short arm. Case Reports in Genetics 20132013 978087. 